\title{
PENGARUH PERAWATAN PERIODONTAL INISIAL TERHADAP KADAR C-REACTIVE PROTEIN PADA PASIEN PERIODONTITIS KRONIS
}

\author{
(EFFECT OF INITIAL PERIODONTAL TREATMENT ON C-REACTIVE \\ PROTEIN LEVELS IN CHRONIC PERIODONTITIS PATIENTS)
}

\author{
Agus Susanto, Ina Hendiani, Yanti Rusyanti, Dede Hadidjah, Sri Wendari \\ Departemen Periodonsia \\ Fakultas Kedokteran Gigi, Universitas Padjadjaran \\ Jl. Sekeloa Selatan I, Bandung 40132 \\ E-mail: agus.susanto@fkg.unpad.ac.id
}

\begin{abstract}
Chronic periodontitis is an inflammation of tooth supporting tissues and may influence C-reactive protein (CRP) levels in blood. The objective of this study was to measure levels of CRP in chronic periodontitis patients after initial periodontal treatment (scalling and root planning) and correlation between CRP and periodontal disease. Sixteen patients with chronic periodontitis consisted of 9 males and 7 females, aged between 30 and 67 years, participated in this study. Probing pocket depths (PPD) and C-reactive protein levels were assessed before and 4 weeks after initial periodontal treatment. Creactive protein levels were measured using immunoturbidimetric method. The mean of C-reactive protein levels before and after initial periodontal treatment was $3.36 \mathrm{mg} / \mathrm{L}$ and $2.0 \mathrm{mg} / \mathrm{L}$, respectively $(\mathrm{p}=0.009)$. Levels of C-reactive protein decreased $40.5 \%$. Regression analysis showed positive correlation between CRP and periodontal disease $(r=0.745 ; \mathrm{p}=$ 0.001). In conclusion, initial periodontal treatment (scalling and root planning) may decrease C-reactive protein levels in chronic periodontitis patients, and have positive correlation between CRP and periodontal disease.
\end{abstract}

Key words: initial periodontal treatment, C-reactive protein, chronic periodontitis

\begin{abstract}
Abstrak
Periodontitis kronis adalah peradangan jaringan pendukung gigi yang dapat mempengaruhi kadar $C$-reactive protein (CRP) dalam darah. Tujuan penelitian ini adalah untuk mengukur kadar CRP pada pasien periodontitis kronis setelah perawatan periodontal inisial (skeling dan root planing) dan menentukan hubungan CRP dengan penyakit periodontal. Enam belas subjek penelitian yang terdiri atas 9 orang laki-laki dan 7 orang perempuan dengan rentang usia antara 30 67 tahun yang menderita periodontitis kronis berpartisipasi pada penelitian ini. Pengukuran kedalaman poket (Probing Pocket Depth/ PPD) dan pengambilan sampel darah untuk pemeriksaan kadar CRP dilakukan sebelum dan 4 minggu setelah perawatan periodontal inisial. Pengukuran kadar CRP dengan menggunakan metode Immunoturbinimetri. Rerata kadar $C$-reactive protein sebelum dan setelah perawatan periodontal inisial 3,36 mg/L dan 2,0 mg/L $(\mathrm{p}=0,009)$. Persentase penurunan kadar CRP sebesar 40,5\%. Analisis regresi menunjukkan hubungan linear positif antara kadar CRP dengan penyakit periodontal $(\mathrm{r}=0,745 ; \mathrm{p}=0,001)$. Sebagai kesimpulan, perawatan periodontal inisial dapat menurunkan kadar CRP pada pasien periodontitis kronis dan terdapat hubungan positif antara kadar CRP dengan penyakit periodontal.
\end{abstract}

Kata kunci: perawatan periodontal inisial, C-reactive protein, periodontitis kronis

\section{PENDAHULUAN}

Penyakit periodontal merupakan proses inflamasi yang disebabkan oleh bakteri yang dapat berkembang menjadi penyakit yang destruktif ketika terjadi interaksi antara bakteri dengan mekanisme pertahanan tubuh. ${ }^{1}$ Respon imun tubuh terhadap infeksi bakteri subgingiva pada periodontitis meng- hasilkan produksi berbagai penanda inflamasi (biomarker inflammatory) seperti interleukin 1 (IL-1) dan $C$-reactive protein (CRP). ${ }^{2}$ Terdapat tiga sitokin proinflammatory yaitu interleukin 1 (IL-1), interleukin 6 (IL-6) dan tumor necrosis factor (TNF) yang berperan dalam kerusakan jaringan periodontal. ${ }^{3}$ Diantara berbagai proinflammatory tersebut, $C$-reactive protein mendapat perhatian dan menarik 
untuk diteliti karena dihubungkan dengan terjadinya aterosklerosis dan menjadi prediksi resiko penyakit kardiovaskular. ${ }^{4,5}$

$C$-reactive protein (CRP) dihasilkan oleh hati yang secara normal bersirkulasi dengan konsentrasi yang sangat rendah $(1-3 \mathrm{mg} / \mathrm{L})$, tetapi pada proses inflamasi akut, inflamasi kronis, infeksi atau cedera pada jaringan dapat menyebabkan peningkatan kadar protein ini. Pada keadaan akut dapat meningkat 100 kali atau lebih, sedangkan pada keadaan inflamasi kronis peningkatan tidak terlalu besar, nilainya mendekati normal yaitu diatas $3,8 \mathrm{mg} / \mathrm{L} .{ }^{6} C$ reactive protein berperan dalam mekanisme pertahanan tubuh pada sistem imun nonspesifik yang dapat mengikat senyawa fosforil kolin pada lapisan kulit terluar bakteri yang masuk ke dalam tubuh dan mengganggu proses perkembangan bakteri tersebut, selain itu dapat mengaktifkan komplemen, meningkatkan laju endap darah dan menyebabkan luka pada arteri. Pengaruh-pengaruh ini menyebabkan kemungkinan terjadinya aterosklerosis. ${ }^{7,8}$

Penyakit periodontal berkorelasi dengan peningkatan kadar CRP, pada pasien yang menderita periodontitis kronis sedang (moderate) dan berat (severe) kadar CRP mengalami peningkatan yang signifikan apabila dibandingkan dengan pasien yang tidak mengalami periodontitis. Pada penderita periodontitis kadar CRP meningkat 30\% lebih tinggi apabila dibandingkan dengan yang tidak menderita periodontitis. Selama ini di Klinik Periodontik Rumah Sakit Gigi dan Mulut Fakultas Kedokteran Gigi Universitas Padjadjaran kadar CRP tidak pernah diperiksa pada pasien periodontitis kronis, oleh karena itu penting untuk diketahui bahwa peningkatan kadar CRP ini berhubungan dengan berbagai penyakit lainnya seperti radang sendi (rheumatoid arhritis), stroke, Diabetes mellitus, TBC dan penyakit jantung. Selain itu kadar CRP dapat dijadikan sebagai salah satu parameter keberhasilan perawatan periodontal pada pasien periodontitis kronis.

Perawatan periodontal inisial yang umum dilakukan pada pasien periodontitis kronis adalah skeling dan root planning. Tujuan tahapan perawatan ini adalah menghilangkan faktor etiologi penyakit periodontal. Tahapan perawatan inisial ini sangat penting dalam rangkaian perawatan periodontal, menurut data penelitian klinis mengindikasikan bahwa keberhasilan perawatan dalam jangka panjang tergantung pada hasil yang didapat selama terapi inisial. ${ }^{9}$ Penelitian ini bertujuan untuk mengukur kadar CRP dalam darah pada pasien periodontitis kronis sebelum dan setelah perawatan inisial (skeling dan root planing), serta menentukan hubungan kadar CRP dengan penyakit periodontal.

\section{BAHAN DAN METODE}

Rancangan penelitian adalah eksperimental semu dengan desain pre and post. Populasi penelitian adalah pasien yang datang ke Klinik Periodonsia Rumah Sakit Gigi dan Mulut Fakultas Kedokteran Gigi Universitas Padjadjaran. Pengambilan sampel secara consecutive sampling, dengan kriteria inklusi: usia lebih dari 30 tahun, jenis kelamin laki-laki atau perempuan, periodontitis kronis sedang (moderate) atau parah (severe). Kriteria ekslusinya adalah wanita hamil, pengguna alat kontrasepsi pil atau suntik, wanita menyusui, menggunakan antibiotik 3 bulan terakhir, riwayat penyakit diabetes melitus dan penyakit kardiovaskular.

Pengukuran kedalaman poket (PPD) dan pengambilan darah vena untuk mengukur kadar $C$-reactive protein (CRP) dalam darah dilakukan sebelum dan setelah 4 minggu perawatan periodontal inisial (skeling dan root planing). Pengukuran kedalaman poket pada semua gigi rahang atas dan rahang bawah dilakukan pada enam permukaan (distobukal, midbukal, mesiobukal, distolingual, lingual dan mesiolingual). Pengambilan sampel darah vena 2-3 cc, pengukuran kadar CRP menggunakan metode Immunoturbidimetri.

Pada prosedur pengukuran kadar CRP, sampel darah disentrifugasi selama 10 menit dengan kecepatan 3000-4000 rpm, sampel pemeriksaan yang dipakai serum darah. Kadar C-reaktif protein diukur dengan metode Immunoturbidimetri Tina quant @ $C$-reactive protein (latex) hight sensitive. Sampel pemeriksaan ditambah reagen 1 (buffer) kemudian ditambah reagen 2 (anti CRP antibody-latex) dan reaksi mulai berlangsung. Anti CRP antibodi yang terikat dalam latex makropartikel bereaksi dengan antigen didalam sampel membentuk antigen antibodi komplek, intensitas yang terbentuk diukur secara turbidimetri. Sensitivitas konsentrasi terendah kadar CRP adalah $0,1 \mathrm{mg} / \mathrm{L}$ dengan jarak pembacaan 0,1$20 \mathrm{mg} / \mathrm{L}$. Jika konsentrasi CRP dalam sampel diatas jarak pembacaan maka dilakukan pengenceran secara manual dengan $\mathrm{NaCl} 0,9 \%$, kemudian hasil pengukuran dikalikan dengan pengenceran yang dilakukan. Alat yang digunakan untuk mengukur kadar CRP adalah Archipec 8200.

Data yang diperoleh dianalisis secara statistik dengan tahapan melakukan uji normalitas data untuk data kuantitatif berdasarkan Shapiro-Wilk. Perbandingan kadar CRP antara sebelum dan setelah perawatan periodontal inisial digunakan uji Wilcoxon. Hubungan kadar CRP dengan penyakit periodontal yang dilihat berdasarkan kedalaman poket (PPD) dianalisis dengan analisis regresi, dengan tingkat kemaknaan hasil uji ditentukan berdasarkan 
nilai $\mathrm{p}<0,05$.

\section{HASIL}

Subyek penelitian sebanyak 16 orang terdiri atas 9 orang laki-laki dan 7 orang perempuan dengan rentang umur 30 tahun sampai dengan 67 tahun. Terdapat perbedaan yang bermakna antara rerata kadar CRP sebelum dan setelah perawatan periodontal inisial dengan nilai $p=0,009(p<0,05)$. Hal ini menunjukkan bahwa perawatan periodontal inisial dapat menurunkan kadar CRP dengan persentase penurunan sebesar 40,5\%. (Tabel 1). Terdapat perbedaan bermakna antara rerata kedalaman probing (PPD) sebelum dan setelah perawatan periodontal inisial dengan nilai $\mathrm{p}=0,001$ (Tabel 2).

Tabel 1. Kadar $C$-reactive protein (CRP) sebelum dan setelah perawatan periodontal inisial

\begin{tabular}{lccc}
\hline \multirow{2}{*}{ Perawatan } & \multicolumn{3}{c}{ Kadar CRP $(\mathrm{mg} / \mathrm{mL})$} \\
\cline { 2 - 4 } & Rata-rata $(X \pm \mathrm{SD})$ & Median & Rentang \\
\hline Sebelum & $3,36 \pm 3,24$ & 1,9 & $0,7-10,9$ \\
Setelah & $2,0 \pm 1,34$ & 1,45 & $0,6-4,9$ \\
\hline $\mathrm{Zw}=2,59 ; \mathrm{p}=0,009$ & &
\end{tabular}

Tabel 2. Kedalaman poket (PPD) sebelum dan setelah perawatan periodontal inisial

\begin{tabular}{cc}
\hline Perawatan & Rata-rata kedalaman poket $(\mathrm{mm})(\mathrm{X} \pm \mathrm{SD})$ \\
\hline Sebelum & $3,25 \pm 0,59$ \\
Setelah & $2,59 \pm 0,45$ \\
$\mathrm{t}=5,85, \mathrm{p}=0,001$ &
\end{tabular}

Hubungan antara CRP dengan kedalaman poket (PPD) dilakukan dengan analisis regresi. Hasilnya menunjukkan adanya hubungan yang bermakna dengan model persamaan regresi:

Kadar $\mathrm{CRP}=-9,751+1,99 \times$ PPD $(\mathrm{r}=0,745 ; \mathrm{p}=$ $0,001)$

Artinya setiap perubahan $1 \mathrm{~mm}$ PPD kadar CRP meningkat sebesar 1,99 dari model regresi tersebut dapat dibuat prediksi taksiran kadar CRP dari berbagai variasi PPD seperti pada Gambar 1 .

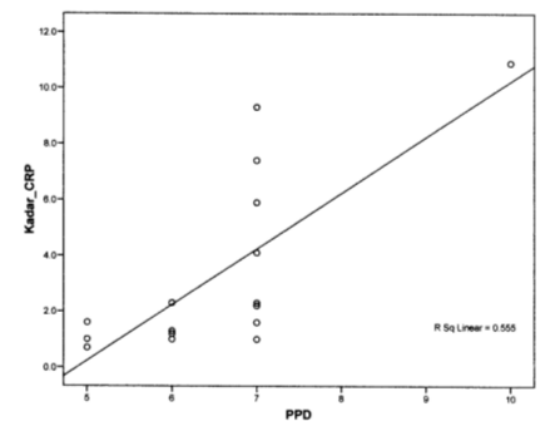

Gambar 1. Hubungan kadar CRP dengan kedalaman poket (PPD)

\section{PEMBAHASAN}

Hasil penelitian menunjukkan periodontitis kronis mempunyai hubungan yang signifikan dengan kadar CRP. Keparahan penyakit periodontal dilihat dari kedalaman poket (PPD), semakin dalam poket maka semakin tinggi kadar CRP. Hasil penelitian ini sesuai dengan penelitian Pitiphat dkk. yang menyatakan bahwa periodontitis dan Porphyromonas gingivalis subgingival berhubungan dengan peningkatan kadar CRP, selain itu sesuai dengan penelitian Fitzsimmons dkk. yang menyatakan keberadaan CRP pada cairan sulkus gusi berhubungan dengan parameter penyakit periodontal. ${ }^{2,5}$

Pada penelitian ini rerata kadar CRP sebelum perawatan 3,36 mg/L dan setelah perawatan 2,0 mg/L. Terdapat perbedaan yang bermakna kadar CRP sebelum dan setelah perawatan periodontal inisial $(p=0,009)$. Hal ini menunjukkan bahwa perawatan periodontal inisial dapat menurunkan kadar CRP pada pasien periodontitis kronis dengan persentase penurunan kadar sebesar $40,5 \%$. Hasil penelitian ini sesuai dengan penelitian sebelumnya yang dilakukan Matilla dkk. Rai Balwant dkk. Penelitian Matilla menunjukkan bahwa perawatan periodontal dapat menurunkan kadar CRP, dengan penurunan yang terjadi $<50 \%$. Rai Balwant dalam penelitiannya menyatakan bahwa perawatan periodontal secara signifikan menurunkan kadar $C$-reactive protein (CRP), tissue plasminogen activator ( $(P A)$ dan low density lipoprotein cholesterol $(L D L-C) .{ }^{10} \mathrm{C}$-reactive protein merupakan tanda adanya proses peradangan dalam tubuh, penurunan kadar CRP karena inflamasi pada jaringan periodontal telah hilang atau berkurang, contohnya seperti setelah dilakukan perawatan inisial (skeling dan root planing).

Kadar CRP pada pasien periodontitis lebih tinggi dari normal, pada penelitian ini rata-rata kadar CRP pada 16 subjek penelitian yang mengalami periodontitis kronis sebesar 3,36 mg/L. Walaupun pada penelitian ini tidak dapat membandingkan kadar CRP pasien periodontitis dengan yang tidak periodontitis namun rata-rata kadar CRP lebih besar dari nilai normal. Hal ini sesuai dengan penelitianpenelitian sebelumnya yang dilakukan oleh Ebersole dan Joshipura. Kadar CRP mengalami peningkatan yang signifikan pada pasien yang menderita periodontitis kronis sedang dan berat dibandingkan dengan pasien yang tidak mengalami periodontitis. Penelitian Joshipura dkk. menyatakan bahwa kadar CRP meningkat 30\% lebih tinggi apabila dibandingkan dengan yang tidak menderita penyakit periodontal. ${ }^{11}$ Peningkatan kadar CRP terjadi karena bakteri patogen periodontal menyebabkan pelepasan sitokin pro inflamasi seperti IL-1, IL-6 dan TNF $\alpha$. 
Peningkatan produksi sitokin ini menyebabkan liver memproduksi reaktan fase akut seperti $C$-reactive protein.

Hasil penelitian ini mendapatkan rerata kedalaman poket sebelum dan setelah perawatan periodontal inisial adalah $3,25 \mathrm{~mm}$ dan $2,59 \mathrm{~mm}$, pengujian secara statistik menunjukkan perbedaan yang sangat bermakna $(p=0,001)$. Hal ini berarti perawatan periodontal inisial skeling dan root planing efektif untuk menurunkan kedalaman poket dengan persentase penurunan sebesar $20 \%$. Hung dan Douglas melakukan meta analisis dari penelitian-penelitian mengenai efek skeling dan root planing terhadap kedalaman poket, hasil meta analisis tersebut memperlihatkan bahwa skeling dan root planing pada poket yang dangkal $(1-3 \mathrm{~mm})$ dapat menurunkan kedalaman poket sebesar $0,15-0,62 \mathrm{~mm}$, untuk poket sedang (4-6 mm) sebesar 0,40-1,70 mm dan untuk poket dalam $(>7 \mathrm{~mm}$ ) sebesar $0,99-2,80 \mathrm{~mm}$. Berkurangnya kedalam poket setelah skeling dan root planing, disebabkan terjadi penciutan gusi dan penambahan perlekatan klinis, penciutan gusi terjadi setelah 1 minggu dan penambahan perlekatan klinis setelah 3 minggu skeling dan root planing. Penyembuhan umumnya lebih banyak terbentuk long junctional epithelium (LJE) daripada new attachment.

Telah banyak penelitian baik penelitian cross sectional dan longitudinal dilakukan untuk melihat hubungan antara periodontitis dan CRP. Alasan tertarik untuk meneliti kadar plasma karena berbagai penelitian epidemiologi menunjukkan adanya hubungan periodontitis dengan penyakit kardiovaskular. Perhatian sekarang ini bahwa CRP merupakan marker yang penting untuk aterosklerosis dan peningkatan CRP menjadi prediksi resiko penyakit kardiovaskular. $^{4}$

Hubungan infeksi penyakit periodontal dengan penyakit kardiovaskuler khususnya aterosklerosis dapat dijelaskan melalui 2 mekanisme yaitu pengaruh langsung bakteri pada pembentukan ateroma dan pengaruh tidak langsung melalui berbagai respons imun tubuh. Bakteri patogen periodontal Porphyromonas gingivalis dapat berinvasi pada sel epitel, connective tissue dan sel endotel. Invasi Porphyromonas gingivalis diperantarai melalui pengaturan molekul adhesi seperti intercellular adhesion molecule 1 (ICAM-1), vascular adhesion molecule 1 (VCAM-1), P-selectin dan E-selectin. Aktivasi molekul adhesi juga diperlukan untuk ikatan leukosit pada endotelium yang dapat menginisiasi atherogenesis. Lipopolisakarida (LPS) bakteri Gram negatif mengaktifkan jalur inflamasi melalui produksi sitokin yaitu tumor necrosis factor, interleukin 1, prostaglandin $E_{2}$. Berbagai sitokin ini menginduksi liver untuk menghasilkan protein fase akut seperti CRP yang dapat mempengaruhi aktivasi dan koagulasi trombosit. ${ }^{9,12}$

Pernyataan American Heart Association mengakui adanya hubungan antara kadar CRP dan resiko terjadinya penyakit jantung koroner, peningkatan resiko terjadi pada kadar CRP lebih dari $3 \mathrm{mg} / \mathrm{L} .{ }^{6}$ Dalam penelitian ini subjek dengan kadar CRP yang lebih dari $3 \mathrm{mg} / \mathrm{L}$ mengalami perubahan dari 5 pasien sebelum perawatan menjadi 3 pasien setelah perawatan periodontal inisial dan 4 pasien mencapai nilai kurang dari $1 \mathrm{mg} / \mathrm{L}$ yang merupakan resiko rendah terjadinya penyakit jantung koroner. Pengaruh negatif peningkatan CRP yaitu mengaktifkan sistem komplemen yang berperan pada pembentukan ateroma. ${ }^{9}$ Penurunan kadar CRP dengan rata-rata kurang dari $3 \mathrm{mg} / \mathrm{L}$ mengindikasikan perawatan periodontal inisial skeling dan root planing dapat menurunkan resiko penyakit kardiovaskular. Status kesehatan mulut terutama penyakit periodontal perlu dicatat dan diperiksa dalam pemeriksaan pasien yang menderita penyakit kardiovaskular.

Berdasarkan uraian diatas, dapat disimpulkan bahwa perawatan periodontal inisial yaitu skeling dan root planing dapat menurunkan kadar CRP pada pasien periodontitis kronis dan terdapat hubungan kadar CRP dengan penyakit periodontal berdasarkan kedalaman poket (PPD).

\section{Daftar Pustaka}

1. Keith L, Mario Taba, Rossa C, Philip M, William. Molecular biology of the host microbe interaction in periodontal disease.In: Newman MG, Takei N, Klokkevold P, eds. Carranza's Clinical Periodontology $10^{\text {th }}$ ed. Philadelphia: WB Saunders Co, 2006: 259-74.

2. Fitzsimmon TR, AE Sanders, GD Slade, PM Bartold. Biomarker of periodontal inflammation in the Australian adult population. Australian Dent $\mathrm{J}$ 2009; 54: 115-22.

3. Russell MJ, Susan Kinder, M Newman and Kenneth Miyasaki. Microbial interaction with the host in periodontal disease. In: Newman MG, Takei N, Klokkevold P, eds. Carranza's clinical priodontology $10^{\text {th }}$ ed. Philadelphia: WB Saunders Co, 2006: 228-50.

4. Paraskevas S, Huizinga JD, Loos BG. A Systematic review and meta-analysis on C-reaktif protein in relation to periodontitis. J Clin Periodontol 2008; 35 : 277-90.

5. Pitiphat W, Savetslip W, Wara aswapati. C-reacive protein associated with periodonitis in a Thai population. J Clin Periodontol 2008; 35: 120-5.

6. William RW. Hight Sensitivity C-reaktif protein and cardiovascular disease. International Health New. <http://www.yourhelathbase.com/heart_CRP.htm> 
(25 April 2010).

7. Bratawidjaja KG. Imunologi dasar $.1^{\text {thed., Jakarta: }}$ Balai penerbit FK UI, 2004; 1-14.

8. Irfan Arief. Resiko baru penyakit kardiovaskular. National Cardiovascular Center Harapan Kita; 2007 <http://www.pjnhk.go.id> (10 Juni 2010).

9. Takei Henry. Non Surgical Therapy. In: Newman MG, Takei N, Klokkevold P, eds. Carranza's Clinical Periodontology $10^{\text {th }}$ ed. Philadelphia: WB Saunders Co 2006:722-7.

10. Rai Balwant, Anand SC. After scaling and root planing lower systemic inflammatory and throm- botic marker of cardiovascular risk. Middle East J Scientific Researh 2007; 2: 54-6.

11. Joshipura KJ, Wand HC, Merchant, Rimm EB. Periodontal disease and biomarkers related to cardiovascular disease. J Dent Res 2004; 83(2): 151-55.

12. Mealey BL, Perry RK. Periodontal medicine: Impact of periodontal infection on systemic health. In: Newman MG, Takei N, Klokkevold P, eds. Carranza's Clinical Periodontology. 10 ${ }^{\text {th }}$ ed. Philadelphia: WB Saunders Co, 2006: 312-29. 